\title{
Effectiveness of Different Fixatives in Body Fluid Analysis
}

\author{
Dr. Sonti Sulochana ${ }^{1}$, Miss. Sudha ${ }^{2}$, Kolappan $^{3}$, Vinodh ${ }^{4}$ \\ ${ }^{1}$ Professor, Department of Pathology, Saveetha Medical College and Hospital, Saveetha Institute of Medical and Technical Sciences, Thandalam \\ ${ }^{2}$ B. Sc. Medical Laboratory Technologist Internship Student \\ ${ }^{3}$ Laboratory Manager \\ ${ }^{4}$ Cytology Laboratory Technologist
}

\begin{tabular}{ll}
\hline DOI: $10.36348 /$ SJPM.2019.v04i09.010 & | Received: 21.09.2019| Accepted: $28.09 .2019 \mid$ Published: 30.09 .2019 \\
*Corresponding author: Dr. Sonti Sulochana &
\end{tabular}

\section{Abstract}

Background: Body fluid samples are routinely received for cytological examination to diagnose inflammatory, benign or malignancy. Diagnostic efficiency depending on the type of fixatives used. Therefore these fluid samples are processed with six different fixatives to study thecytomorphological changes. Aim and objectives: 1 .The aim of the study was to study as closely as possible the cytomorphological characteristics of body fluids by different fixatives. 2 . To compare and analyse the most effective fixative. Materials and method: Inpresent study, the body fluid samples were received from various out-patient and inpatient departments of saveetha medical college and hospital (from Jan 2019 to March 2019). About 50 body fluid samples of various patients is collected for morphological examination .The moderate amount of fluid $(10 \mathrm{ml}$ to $15 \mathrm{ml})$ were processed by centrifugation, then smeared and stained. Results: Schaudins and carnoys fixatives are the best among the other six different fixatives which had an excellent nuclear and cytoplasmic features and clear background. Conclusion: Isopropyl alcohol using as an ideal fixative in ctytology laboratory. But Schaudins and carnoys are also as best fixative as that of isopropyl alcohol in body fluid cytology

Keywords: fixative, body fluids, hematoxylin and eosin, centrifuge.

Copyright @ 2019: This is an open-access article distributed under the terms of the Creative Commons Attribution license which permits unrestricted use, distribution, and reproduction in any medium for non-commercial use (NonCommercial, or CC-BY-NC) provided the original author and sources are credited.

\section{INTRODUCTION}

The cytologic study of body fluids is one of the oldest applications of cytologic techniquesfirst investigated in the latter half of the $19^{\text {th }}$ century.For many years efforts have been made to develop methods that would enhance the sensitivity and specificity of the smear. Preservation of cellular morphology until the sample can be processed is essential to accurate cytologicinterpretation . "prefixation " refers to the collection of a fluid specimen in a medium that will preserve morphology up to the time of slide preparation . Afresh sample is one to which fixative has been added.The accuratediagnosis ofcytoloical smears are based on how fluid samples are fixed. The purpose of cytologic fixatives is to maintain the cytomorphologic characteristics of the cell [1].

An appropriate fixative for cytodiagnosis of fluids should perform the following functions.

- Penetrate cells rapidly

- Minimize cell shrinkage

- Maintain morphologic integrity

- Deactivate autolytic enzymes

- Replace cellular water.
- Facilitate diffusion of dyes across cell boundaries

- Helps cell adherence to a glass surface 8. Provide consistent results over time

- Produce a permanent cell record 10.Stop cellular and microbial growth (anti -microbial).

Body fluids samples are collected from pleural, peritoneal, pericardial cavities and joint spaces. This is divided into intracellular and extracellular in a two to one ratio, 28-32 liters are inside the cells and 1415 liters outside the cells. These body fluid samples may contain blood, mucus, inflammatory cells, microbial agents, crystals, proteinaceous material or other debris limiting specimen adequacy.Gross appearance of effusions gives indication about its causes and nature of cellular contents. Haemorrhagic effusions are common findings, these may be pathological (malignancy, tuberculosis, etc). Proper fixation of body fluids is essential when it comes to laboratory for analysing cytological changes.If smears are allowed to dry prior to fixation, marked distortion of cells occurs [2]. So rapid fixation of smears is necessary to preserve cytologic detail of cells. The smears are spreading on a glass slide and stained by $\mathrm{H} \& \mathrm{E}$ staining.This study has been undertaken to improve the 
quality of morphology of cells and their background. And to identify cytomorphological details of smears and also to find out the most effective fixative by using various (6different) fixatives (carnoys, schaudinns, ether alcohol, gender, formalol, isopropyl alcohol).

\section{MATERIALS AND METHODS}

This study includes pleural fluid, synovial fluid, cerebrospinal fluid, asciticfluid, pericardial fluid from various wards and departments of $\mathrm{SMCH}$ (Saveetha Medical College and Hospital) over a period from January 2019 to march 2019 (50 body fluid samples). Fluids with quantity less than $2 \mathrm{ml}$ were excluded from the study. This study was approved by Institutional Review Board.

Received samples were examined under following headings:

Physical examination (volume, colour, cobweb formation)

Processing, smearing and fixation

Staining of smear samples

Cytological examination. The received sample after physical examination (table 2) is collected for fixationand processing. Specimens without preservative are facilitate for immediate processing, the length of time between collection and preparation of the sample before cellular damages occur depends on the $\mathrm{pH}$ protein content, enzymatic activity, and the presence or absence of bacteria [1, 3].

\section{METHODOLOGY}

Put the sample in clean air tight centrifuged tube. Rotate the tube at 1500 rounds per minute (RPM) for 5 minutes in Cytocentrifugation (REMI R-8C) (10) (Fig 1). Discard the supernatant fluid. Make multiple smears from the sediments on a clean glass slide. If RPM is more than $1500 / 10$ minutes may cause morphological distortion of cells, so carefull attention should be given in this aspect. The smears are then fixed immediately in six different fixatives and stained by H\&E method and then mounted[8]. (Fig 2). IfSpecimens consisting of small amount of sediment material that adhere well to glass slides can be smeared directly on the slide using a steady motion. The smears were made to the respective labelling slide. (e.g: the samples are smeared based on the labelling of the slide either with patients name or patient identification number).

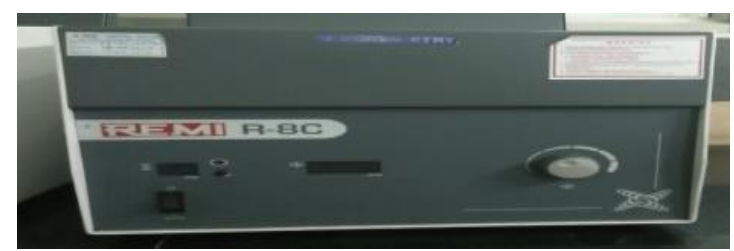

Fig-1: Cytocentrifuge

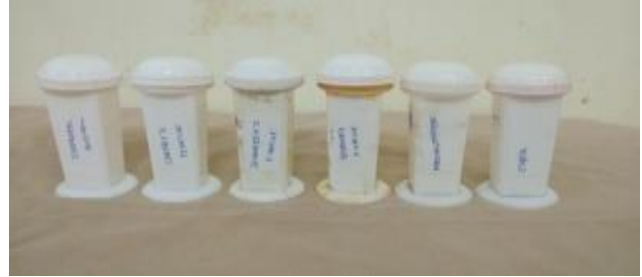

Fig-2: Fixation of smears in different fixatives

\section{FIXATIVES}

Cytological fixatives are very much important to preserve intracellular structures or inclusion $[4,7]$.

\section{In this study, the fixative prepared is}

\section{CARNOYS FIXATIVE (alcohol containing fixative)}

95\% Ethanol60ml

Chloroform $30 \mathrm{ml}$

Glacial acetic acid $10 \mathrm{ml}$

This fixative must be prepared fresh when needed and discarded after each use. This fixative will hemolyze red blood cells and therefore is useful for bloody specimens. Nuclear chromatin will be lost if the cell samples remains in carnoy's fixative for longer than 15 minutes. It penetrates rapidly and is excellent nuclear fixative $[4,7]$.

\section{ETHER ALCOHOL (cytoplasmic fixative) Ether $25 \mathrm{ml}$ Alcohol 25ml}

Ideal fixative, good dehydrating agent and it causes desired amount of cell contraction. This also yields optimal chromatin detail characteristics. The fixation time is 15 minutes, can be prolonged, several days or even fewer weeks. If smears are to be preserved over a long period of time in alcohol, it is better to store them in captured containers in the refrigerator.

\section{SCHAUDINNS FIXATIVE}

Mercuric chloride, saturated aqueous solution 2 parts, Absolute alcohol 1part. This fixative has been popular for many reasons as a cytoplasmic fixative for wet smears. Wet smears are well fixed in 10-20 minutes unless too thick rarely becomes subsequently detached from the slide. This fixative should be prepared immediately.

\section{GENDERS FIXATIVE}

Picric acid saturated in aqueous solution $\quad 75 \mathrm{ml}$ Formalin (40\% formaldehyde) $\quad 25 \mathrm{ml}$ Glacial acetic acid $\quad 5 \mathrm{ml}$

This fluid is said to give good fixation of glycogen, after 3-4 hours at room temperature.

\section{FORMAL ALCOHOL}

Formalin $10 \mathrm{ml}$

70-95 per cent alcohol $90 \mathrm{ml}$ 
If desired, $0.5 \mathrm{~g}$ of calcium acetate can be added to ensure neutrality.

6.80\% ISO PROPYL ALCOHOL:

90\% ISO PROPYL ALCOHOL

\section{WATER 10\%}

Naturally colorlessmay contain coloradditives. This fixative can be used for about 7 days and it does not involve immediate preparation. It is the most commonly used fixative of choice.

After fixation the smears are then stained with routine haematoxylin and eosin stain.

Haematoxylin 5g

Absolute alcohol $50 \mathrm{ml}$

Alum $100 \mathrm{~g}$

Distilled water $1000 \mathrm{ml}$

Mercuric oxide $2.5 \mathrm{~g}$

EOSIN:

Eosin Y $16 \mathrm{~g}$

Potassium dichromate $8 \mathrm{~g}$

Picric acid $160 \mathrm{ml}$

$95 \%$ alcohol $160 \mathrm{ml}$

Distilled water $1280 \mathrm{ml}$
The smears are placed in haematoxylin for 3-5 minutes, then washed in running tap water for 2 seconds which then undergoes differentiation in alcohol followed by washing in tap water (bluing) and are then placed in eosin for $2 \mathrm{sec}$. The slides are then mounted and kept ready to pathologists for observation or analysis.

\section{OBSERVATION AND RESULTS}

A total of50 body fluid samples were taken in this study,in which maximum number were pleural fluid $52 \%$ of cases followed by asictic fluid $32 \%$ cases, synovial fluid $12 \%$ of cases followed by CSF, pericardial and peritoneal fluid $2 \%$ of each cases(Table 1).In present study, maximum number of cases were males and ratio of male to female $1: 8: 1$ (Table- 2$)$ the smears were observed for morphology of nucleus and cytoplasm and background by semiquantative scoring system. The cytomorphological details were observed in carnoys fixative followed by ether alcohol, $80 \%$ iso propyl alcohol, genders fixative, schaudins, and formal alcohol (Table 3).

Table-1: Total numberand the percentage of the fluids analysed

\begin{tabular}{|l|l|l|l|}
\hline S.No & Body fluids & No of cases & percentage \\
\hline 1 & Plueral fluid & 26 & $52 \%$ \\
\hline 2 & Ascitic fluid & 16 & $32 \%$ \\
\hline 3 & Synovial fluid & 6 & $12 \%$ \\
\hline 4 & CSF & 1 & $2 \%$ \\
\hline 5 & Pericardial fluid & 1 & $2 \%$ \\
\hline 6 & Peritoneal fluid & 1 & $2 \%$ \\
\hline
\end{tabular}

Table-2: (Age and Sex and physical characteristics of various body fluids)

\begin{tabular}{|c|c|c|c|c|c|c|}
\hline $\begin{array}{c}\text { S.N } \\
\text { O }\end{array}$ & UHID & $\begin{array}{c}\text { Type of } \\
\text { specimen }\end{array}$ & VOLUME & COLOUR & AGE/SEX & DIAGNOSIS \\
\hline 1 & 1901030120 & Ascitic fluid & $10 \mathrm{ml}$ & PALE YELLOW & $13 / \mathrm{F}$ & CAD/T2DM \\
\hline 2 & 1701050217 & Pleural fluid & $8.2 \mathrm{ml}$ & REDDISH & $70 / \mathrm{F}$ & LRRT \\
\hline 3 & 1712110201 & Synovial fluid & $9.6 \mathrm{ml}$ & PALE YELLOW & $54 / \mathrm{M}$ & STS/GOUT \\
\hline 4 & 1901070243 & Peritoneal fluid & $5.4 \mathrm{ml}$ & REDDISH & $41 / \mathrm{F}$ & $\begin{array}{c}\text { ACUTE } \\
\text { APPENICITIS }\end{array}$ \\
\hline 5 & 1901070156 & Synovial fluid & $4.1 \mathrm{ml}$ & PALE YELLOW & $51 / \mathrm{M}$ & R-LL CELLULITIS \\
\hline 6 & 1812300421 & Pleural fluid & $6.9 \mathrm{ml}$ & YELLOW & $63 / \mathrm{F}$ & CKD \\
\hline 7 & 1803280832 & Ascitic fluid & $10.3 \mathrm{ml}$ & TURBID YELLOW & $83 / \mathrm{F}$ & DCLD \\
\hline 8 & 1812190312 & Pleural fluid & $8.8 \mathrm{ml}$ & REDDISH & $58 / \mathrm{F}$ & RIGHT PL. EF \\
\hline 9 & 1901100038 & Pleural fluid & $6.9 \mathrm{ml}$ & GREYISH WHITE & $75 / \mathrm{M}$ & L SIDED EMPHYMA \\
\hline 10 & 1812310283 & Ascitic fluid & $5.8 \mathrm{ml}$ & YELLOW & $25 / \mathrm{M}$ & CKD \\
\hline 11 & 1703210052 & Ascitic fluid & $4.8 \mathrm{ml}$ & PALE YELLOW & 29/M & INTESTIAL TB \\
\hline 12 & 1901210002 & Ascitic fluid & $9 \mathrm{ml}$ & YELLOW & $53 / \mathrm{M}$ & DCLD \\
\hline 13 & 1901210281 & Pleural fluid & $8.3 \mathrm{ml}$ & YELLOW & $62 / \mathrm{M}$ & RPL.EF \\
\hline 14 & 1901210153 & Pleural fluid & $6.5 \mathrm{ml}$ & PALE YELLOW & $32 / \mathrm{M}$ & $\begin{array}{c}\text { PLEURAL } \\
\text { EFFUSSION }\end{array}$ \\
\hline 15 & 1901210177 & Pleural fluid & $8.2 \mathrm{ml}$ & REDDISH & $31 / \mathrm{M}$ & CKD/SHTN \\
\hline 16 & 1901210228 & Pleural fluid & $7.9 \mathrm{ml}$ & YELLOW & $30 / \mathrm{F}$ & LUNG ABSESS \\
\hline 17 & 1902250434 & Pericardial fluid & $8 \mathrm{ml}$ & YELLOW & $38 / \mathrm{F}$ & $\begin{array}{l}\text { PERICARDIAL } \\
\text { EFFUSION }\end{array}$ \\
\hline 18 & 1902110096 & Pleural fluid & $6.2 \mathrm{ml}$ & TURBID YELLOW & $59 / \mathrm{M}$ & EMPHYMA \\
\hline 19 & 1902129004 & Pleural fluid & $8.3 \mathrm{ml}$ & YELLOW & $51 / \mathrm{M}$ & HEAD INJURY \\
\hline 20 & 1606230001 & Ascitic fluid & $9.3 \mathrm{ml}$ & YELLOW & $42 / \mathrm{M}$ & GASTRITIS \\
\hline 21 & 1902090278 & Ascitic fluid & $5.6 \mathrm{ml}$ & PALE YELLOW & $47 / \mathrm{M}$ & ANAEMIA \\
\hline 22 & 1612310044 & CSF & $3.2 \mathrm{ml}$ & PALE YELLOW & $62 / \mathrm{M}$ & AGA/SEPSIS \\
\hline
\end{tabular}


Sonti Sulochana et al; Saudi J Pathol Microbiol, Sep. 2019; 4(9): 682-688

\begin{tabular}{|c|c|c|c|c|c|c|}
\hline 23 & 1902022524 & Ascitic fluid & $6.3 \mathrm{ml}$ & YELLOW & $76 / \mathrm{M}$ & ASCITIS \\
\hline 24 & 1901170008 & Ascitic fluid & $9.8 \mathrm{ml}$ & YELLOW & $28 / \mathrm{M}$ & DCLD \\
\hline 25 & 1808100374 & Pleural fluid & $8.3 \mathrm{ml}$ & YELLOW & $35 / \mathrm{M}$ & TB EFFUSSION \\
\hline 26 & 1808140011 & Pleural fluid & $7.4 \mathrm{ml}$ & PALE YELLOW & $44 / \mathrm{M}$ & $\begin{array}{l}\text { HYDROPNEUMO } \\
\text { THORAX }\end{array}$ \\
\hline 27 & 1803120301 & Pleural fluid & $8.3 \mathrm{ml}$ & PALE YELLOW & $55 / \mathrm{F}$ & B/L PL.EFF \\
\hline 28 & 1902260119 & Pleural fluid & $5.4 \mathrm{ml}$ & REDDISH & $28 / \mathrm{M}$ & COPD \\
\hline 29 & 1902240398 & Pleural fluid & $5.6 \mathrm{ml}$ & YELLOW & $39 / \mathrm{M}$ & $\begin{array}{c}\text { LOBULAR } \\
\text { PNEUMONIA }\end{array}$ \\
\hline 30 & 1905264310 & Pleural fluid & $9.3 \mathrm{ml}$ & YELLOW & $54 / \mathrm{M}$ & COPD/T2DM/CKD \\
\hline 31 & 1905260410 & Plueral fluid & $8.6 \mathrm{ml}$ & REDDISH & $37 / \mathrm{F}$ & HEMATO THROAX \\
\hline 31 & 1802560143 & Pleural fluid & $6.2 \mathrm{ml}$ & YELLOW & $45 / \mathrm{F}$ & TB \\
\hline 32 & 1905060425 & Pleural fluid & $7.8 \mathrm{ml}$ & YELLOW & $35 / \mathrm{F}$ & PLEURAL EMPYMA \\
\hline 33 & 1905060210 & Ascitic fluid & $6.5 \mathrm{ml}$ & PALE YELLOW & $51 / \mathrm{M}$ & GASTRITIS \\
\hline 34 & 1905062315 & Synovial fluid & $7.3 \mathrm{ml}$ & PALE YELLOW & $32 / \mathrm{M}$ & $\begin{array}{l}\text { RHEUMATIC } \\
\text { ATHRITI }\end{array}$ \\
\hline 35 & 1708045012 & Ascitic fluid & $7.8 \mathrm{ml}$ & YELLOW & $26 / \mathrm{M}$ & $\begin{array}{l}\text { NEPHROTIC } \\
\text { SYNDROME }\end{array}$ \\
\hline 36 & 1905062310 & Pleural fluid & $8.6 \mathrm{ml}$ & YELLOW & $54 / \mathrm{M}$ & $\begin{array}{l}\text { LEFT LUNG } \\
\text { EFFUSSION }\end{array}$ \\
\hline 37 & 1506020375 & Ascitic fluid & $8.9 \mathrm{ml}$ & REDDISH & $37 / \mathrm{F}$ & PANCTOPENIA \\
\hline 38 & 1502304120 & Pleural fluid & $7.3 \mathrm{ml}$ & PALE YELLOW & $36 / \mathrm{F}$ & BRONCHITITIS \\
\hline 39 & 1701236589 & Pleural fluid & $8.6 \mathrm{ml}$ & YELLOW & $35 / \mathrm{M}$ & $\begin{array}{l}\text { PLEURAL } \\
\text { EMPHYMA }\end{array}$ \\
\hline 40 & 1906031205 & Synovial fluid & $4.3 \mathrm{ml}$ & YELLOW & $26 / \mathrm{F}$ & CKD/SHTN \\
\hline 41 & 1905678941 & Ascitic fluid & $8.1 \mathrm{ml}$ & YELLOW & $29 / \mathrm{F}$ & $\begin{array}{c}\text { L L DIABETIC FOOT } \\
\text { ULCER }\end{array}$ \\
\hline 42 & 1924654130 & Pleural fluid & $10 \mathrm{ml}$ & PALE YELLOW & $41 / \mathrm{M}$ & PNEMONIA \\
\hline 43 & 1459876655 & Synovial fluid & $5.3 \mathrm{ml}$ & YELLOW & $54 / \mathrm{F}$ & ARTHRITIS \\
\hline 44 & 1542011545 & Pleural fluid & $7.4 \mathrm{ml}$ & YELLOW & $61 / \mathrm{F}$ & CA LUNG \\
\hline 45 & 1545460056 & Pleural fluid & $6.2 \mathrm{ml}$ & BRIGHT YELLOW & $36 / \mathrm{M}$ & $\begin{array}{l}\text { PLEURAL } \\
\text { EFFUSION }\end{array}$ \\
\hline 46 & 1402456121 & Ascitic fluid & $8.5 \mathrm{ml}$ & REDDISH & $34 / \mathrm{F}$ & $\begin{array}{l}\text { NEPHROTIC } \\
\text { SYNDROME }\end{array}$ \\
\hline 47 & 1905062045 & Pleural fluid & $5.9 \mathrm{ml}$ & YELLOW & $39 / \mathrm{F}$ & CKD/SHTN \\
\hline 48 & 1904563220 & Ascitic fluid & $9.3 \mathrm{ml}$ & PALE YELLOW & $29 / \mathrm{M}$ & ANAEMIA \\
\hline 49 & 1906556222 & Ascitic fluid & $6.5 \mathrm{ml}$ & YELLOW & $46 / \mathrm{M}$ & HTN/GASTRITIS \\
\hline 50 & 5465461146 & Synovial fluid & $8.2 \mathrm{ml}$ & REDDISH & $45 / \mathrm{F}$ & $\begin{array}{l}\text { PRE PETTALAR } \\
\text { EFFUSSION }\end{array}$ \\
\hline
\end{tabular}

\section{DISCUSSION}

The body cavities in human are lined by the two layers of mesothelium -visceral and parietal. There are three important cavities which includes - the pleural covering the lungs, the peritoneal enclosing gastrointestinal tract organs and pericardial covering the heart. In the absence of disease the two layers of these cavities are separated by a thin layer of lubricating fluid to facilitate the movements of the membranes against one another [5].

In disease conditions, excess fluid accumulates within these cavities constituting effusion which may be either a transudate or exudate [9].

Investigations of the effusions by cytologic examination are of much importance in the diagnosis of disease as well as for exclusion of neoplasia. A cytologic examination of the fluid performed on the smears of centrifuged specimens helps in the planning of treatment.It eliminates the need for invasive procedures and unnecessary surgical intervention, thus making the pathologist contribute positively to the clinical diagnosis and management of patients.

Different body fluids were used in the study. They include pleural fluid, peritoneal fluid, cerebrospinal fluid, synovial fluid, pericardial and ascitic fluid.

Volume and gross appearance of the fluid specimen should be documented as soon as the fluid specimen is received, sincegross examination of fluid will aid in the diagnosis.

Features like volume, color, clarity, opalascence, odour, and viscosity should be assessed.

1) Volume will give an idea about the cytopreparatory technique. 2. Colour of the fluid will guide diagnosis. Most of the malignant effusions are grossly blood stained but only proportions of them are positive for malignant cells. Cyto centrifugation helps in concentrating the cellsand the fluid to becentrifuged at $2000 \mathrm{rpm}$ for 10 minutes. Thesupernent fluid 
discarding and the sediment is placed on slide and making as smears. Direct smears are prepared from fresh unfixed thick or turbid fluids. It is done by placing a drop of fluid directly on the slide and smearing it.

Cytological examination of body fluids is of distinct value in confirming or disapproving malignant metastatic tumours to the cavities [6]. Since mesothelial and synovial tumors are rare, this method is useful to detect malignant cells to the body cavities. In other studies the primary site of malignancy was mainly the breast and lung and hence the pleural cavity was more frequently involved. In our experience the immediately processed samples showed cells that retained their morphology to a considerable extent. Fresh samples offer several important advantages compared to samples collected in preservatives. If the fluids were fixed in various fixatives, they are easier to handle, cells are sticker and can adhere well to the glass slides and it is also our choice to use different fixative. All these features have been noted in our study. The smears were made and reported by pathologist. The smear showed good morphological characters of nucleus and cytoplasm in certain fixatives. In our study we had 50 cases of body fluids collected from various body cavities.52\% of pleural, $32 \%$ of asciticfluid, $12 \%$ of synovial fluid and $2 \%$ of CSF, pericardial fluid, peritoneal. It is interesting to note that smears fixed in Carnoy's and Schaudinns showed better nuclear and cytoplasmic details with a clear background. This is explained by the fact that Schaudinns and Carnoys are good fixatives for body fluids (Fig 5, 8). In ether, the background shows vaculation around the nucleus although the staining of nucleus was good, but showed shrinkage of nucleus because of the fact that it causes desired amount of cell contraction(Fig 6). The advantage of ether fixative is the fixation time can be prolonged several days or even fewer weeks, if smesars are to be preserved over a long period of time, it is better to store them in captured containers in the refrigerator. In formal alcohol there is no clear background and it showed shrunken cells of RBC'S, staining of other cells was pale. If desired $0.5 \mathrm{~g}$ of calcium acetate can be added to ensure neutrality(Fig-3) In Gender's fixative there is a reduced size of cells and background clarity was not clear, chromatin details were not clear, cytoplasm of the cells are not good compared to other fixatives. The smears were unsatisfactory when fixed and examined using Gender's fixative (Fig-4). Isopropyl alcohol shows mild pale staining of cells and sometimes chromatin details are not clear. However, it is most commonly used fixative because of its easy availability and cost effective (fig7).

Table-3: Comparation of cytomorphological features of body fluids using various fixatives by semiquantative scoring system

\begin{tabular}{|c|c|c|c|c|}
\hline Nuclearfeatures & Score 0 & Score 1 & Score 2 & Score 3 \\
\hline Ether & & & $\sqrt{ }$ & \\
\hline Isopropyl & & & $\sqrt{ }$ & \\
\hline Formalol & & & $\sqrt{ }$ & \\
\hline Carnoys & & & & $\sqrt{ }$ \\
\hline Genders & & $\sqrt{ }$ & & \\
\hline Schaudinns & & & & $\sqrt{ }$ \\
\hline CYTOPLASMIC FEATURES & Score 0 & Score 1 & Score 2 & Score 3 \\
\hline Ether & & & $\sqrt{ }$ & \\
\hline Formalol & & & $\sqrt{ }$ & \\
\hline Carnoys & & & & $\sqrt{ }$ \\
\hline Genders & & $\sqrt{ }$ & & \\
\hline Schaudinns & & & & $\sqrt{ }$ \\
\hline Isopropyl & & & $\sqrt{ }$ & \\
\hline $\begin{array}{l}\text { Background } \\
\text { features }\end{array}$ & Score 0 & Score 1 & Score 2 & Score 3 \\
\hline Ether & & & & $\sqrt{ }$ \\
\hline Isopropyl & & & & $\sqrt{ }$ \\
\hline Formalol & & & & $\sqrt{ }$ \\
\hline Carnoys & & & & $\sqrt{ }$ \\
\hline Genders & & & & $\sqrt{ }$ \\
\hline Schaudinns & & & & $\sqrt{ }$ \\
\hline Quality of cells & Score 0 & Score 1 & Score 2 & Score 3 \\
\hline Ether & & & & $\sqrt{ }$ \\
\hline Isopropyl & & & & $\sqrt{ }$ \\
\hline Formalol & & & & $\sqrt{ }$ \\
\hline Carnoys & & & & $\sqrt{ }$ \\
\hline Genders & & & $\sqrt{ }$ & \\
\hline Schaudinns & & & & \\
\hline
\end{tabular}

Score 0- Unsatisfactory. Score 1- Satisfactory Score 2 - Good Score 3 - Excellent. 
Table-4: Total score of each fixative

\begin{tabular}{|l|l|l|l|}
\hline Sno & Name of the fixative & Overall score & Percentage (\%) \\
\hline 1 & Ether & 08 & $66 \%$ \\
\hline 2 & Isopropyl & 10 & $83 \%$ \\
\hline 3 & Formalol & 09 & $75 \%$ \\
\hline 4 & Carnoys & 12 & $100 \%$ \\
\hline 5 & Genders & 07 & $58 \%$ \\
\hline 6 & Schaudinns & 12 & $100 \%$ \\
\hline
\end{tabular}

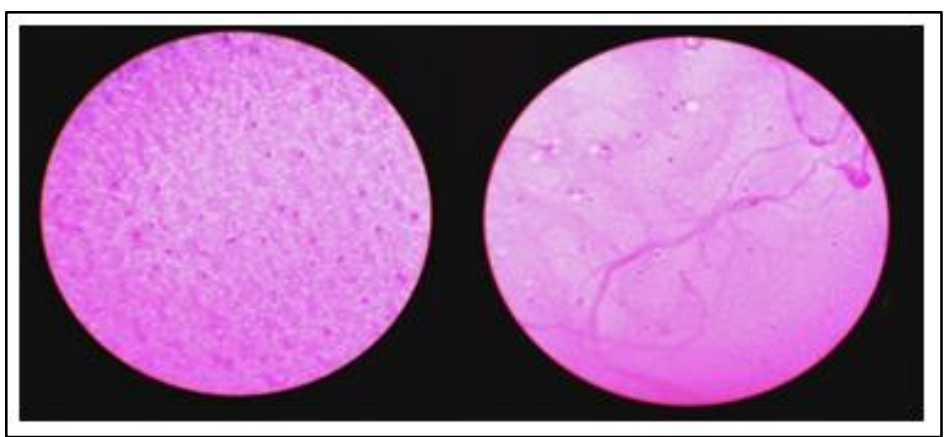

Fig-3: a, b formal alcohol fixative (40x) poor morphology of cells and background

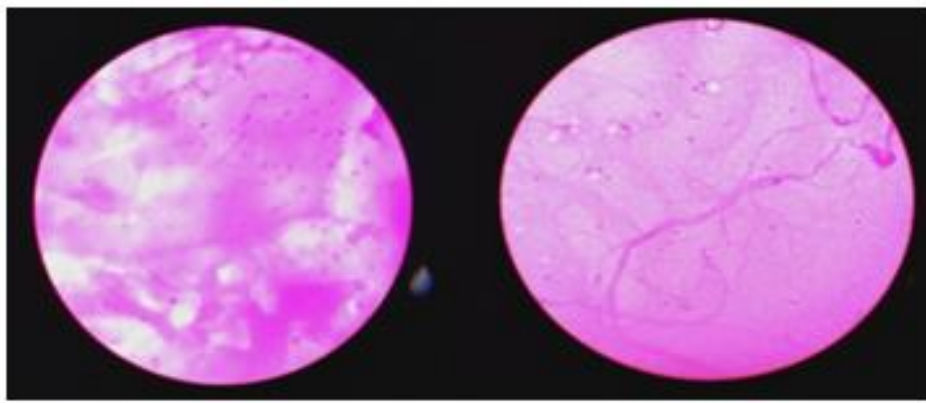

Fig-4: a, b Gender's fixative (40x)-poor morphology of cells and background

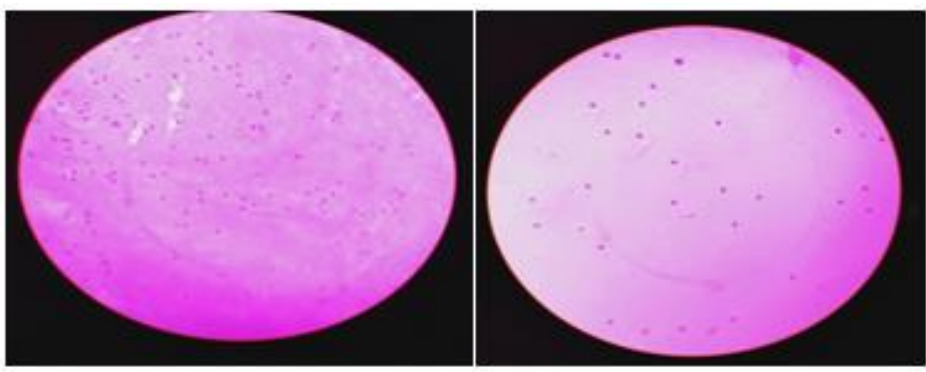

Fig-5a, b.carnoy's fixative (40X)Good nuclear and cytoplasmic staining in clear background

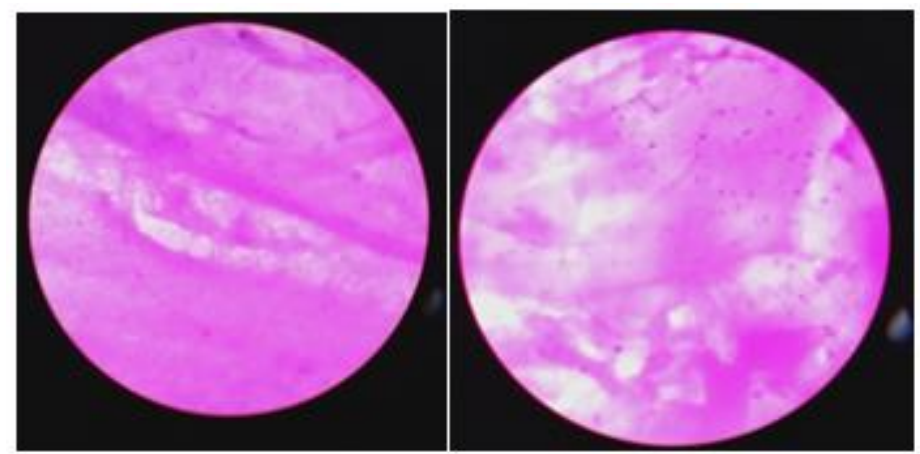

Fig-6: Ether alcohol fixative- nuclear, cytoplasmic and background vacuolation 


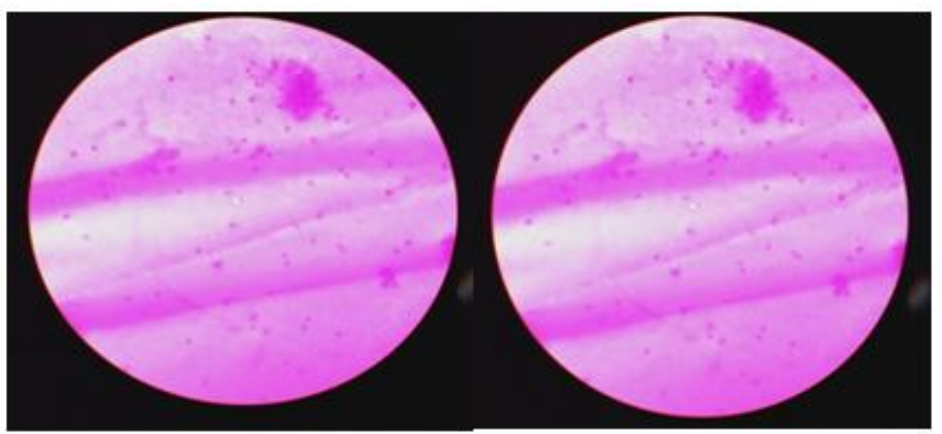

Fig-7: Isopropyl alcohol- mild pale staining of cells in an eosinophilic ground

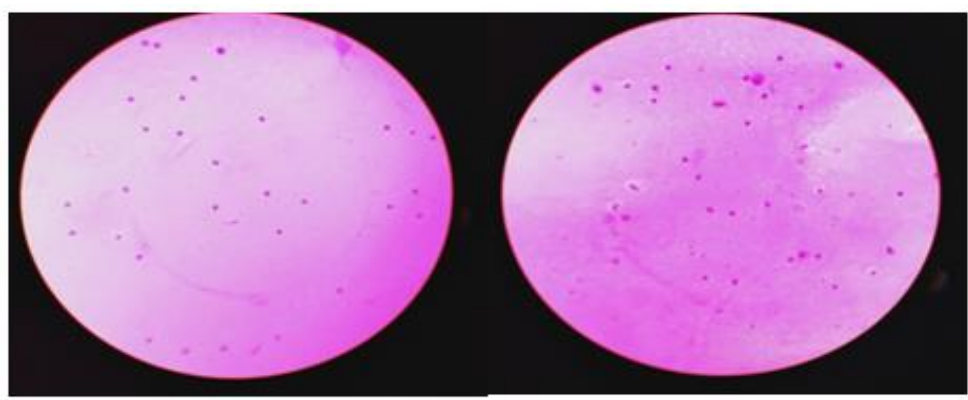

Fig-8: Schauddin's Fixative- good nuclear, cytoplasm and clear background

\section{CONCLUSION}

It has been concluded that Schaudinn's andCarnoy's fixative are best for processing body fluids. Carnoy's penetrates very rapidly and gives excellent nuclear fixation. Quiet faster in their action, fixation completes within 15-20 minutes, useful in cytology to clear heavily blood stained smear, no shrinkage of cells, it gives clear cytoplasmic membrane and nuclear staining with a clear background. Schaudinn's has been popular for many reasons as a cytoplasmic fixative it gives a good staining quality with a clear background and even the lobes of the neutrophil and other cells are very clear including the cytoplasmic borders. As a mercuric chloride based fixative used to preserve the integrity of sample specimen in preparation and analysis. Ether was also good cytological fixative. Isopropyl alcohol was a common cytological fixative used in almost all the labs. According to our study formal alcohol and Gender fixatives are not suitable for the study of body fluids, because of poor morphology of cells and background. According to our study the suitable fixatives in body fluid analysis was showed in the descending order are Carnoy's, Schaudinn's, Ether, Isopropyl alcohol, formal alcohol and Gender fixative.

\section{ACKNOWLEDGEMENT}

Am thankful to our technician vinodh, and Labmanager kolappan, who are helped and supported in this project

\section{REFERENCE}

1. Koss -A book of diagnostic cytology and its histopathology basis volume $2,5^{\text {th }}$ edition chapter 31 , cytopreparatory techniques.

2. Benjammin, Cummings - introduction to body fluids.

3. Pranavdev - introduction to histopathology and cyto techniques, chapter 13 , cytology sample processing.

4. Ramdassnayak - Histopathology techniquesand its management, chapter 2- fixatives and fixation.

5. Jyotisinghrajput - a comparative study of processing of haemorrhagic body fluids by different hemolysing techniques.

6. Swathy, P.U. - dissertation on comparison between liquid based cytology a conventional preparatory methods in body fluid cavity.

7. Culling C.F.A. - handbook of histopathological and histochemical techniques.

8. Leicabiosystems - fixation and staining echniques.

9. Gia - Khanhnguyen - essentials of fluid cytology.

10. Ashok kumardeshpande - comparative study of body fluid cytology using cytospin 2 and ordinary centrifuge. 